\title{
Effects of Rainfall Harvesting and Mulching Technologies on Water Use Efficiency and Crop Yield in the Semi-arid Loess Plateau, China
}

\author{
Zhongkui Xie $^{1}$, Yajun Wang ${ }^{{ }^{*}}$, Sukhdev S. Malhi ${ }^{2}$, Cecil Vera ${ }^{2}$, Yubao Zhang ${ }^{1}$ and Jinniu Wang ${ }^{1}$ \\ ${ }^{1}$ Cold and Arid Regions Environmental and Engineering Research Institute, Chinese Academy of Sciences, Lanzhou \\ 730000, China (*Correspondence: w.yajun@yahoo.com) \\ ${ }^{2}$ Agriculture and Agri-Food Canada, Research Farm, P.O. Box 1240, Melfort, Saskatchewan, Canada S0E 1A0
}

\section{Background}

- In the northwest Loess Plateau of China with mean annual precipitation ranging between 250 and $350 \mathrm{~mm}$, soil moisture is generally limited and crop growth is stressed by drought during the growing season, resulting in decreased and unsustainable crop yields.

- In this semi-arid region with low rainfall, for optimum crop growth and yield irrigation is needed.

- But in most sloping fields, crops are grown under rainfed conditions. In addition, some irrigated crops are also forced to cease irrigation or reduce irrigation times to restrict irrigation amount due to high costs.

- Recent research has shown that some practical techniques, such as methods of rainwater harvesting and supplementary irrigation, can be used to improve crop yields and production stability of the farmland ecosystem.

- There is limited information on this techniques for this low precipitation area.

\section{Objective}

- To determine the influence of ridge and furrow rainfall harvesting system (RFRHS), surface mulching and supplementary irrigation in various combinations on rainwater harvesting, amount of moisture in soil, water use efficiency (WUE), and biomass yield of sweet sorghum (Sorghum bicolour L.) or seed yield of maize (Zea mays L.).

\section{Materials and Methods}

- Field experiments were conducted in 2005 and 2006 at the Gaolan Research Station, Chinese Academy of Sciences, Gansu, China.

- For sweet sorghum, there were 8 treatments (1 to 8) in 2005 and 10 treatments in 2006: (1) plastic-mulched field at planting (conventional; PMFd); (2) plastic-mulched field at planting plus supplementary irrigation $30 \mathrm{~mm}$ under the film (PMFd-SI30); (3) plastic-mulched planting plus supplementary irrigation $60 \mathrm{~mm}$ under the film (PMFd-SI60); (4) RFRHS with plasticcovered ridge and bare furrow (RFRHS-PCR-BFr); (5) RFRHS with plastic-covered ridge and plastic-mulched furrow (RFRHS-PCR-PMFr); (6) RFRHS with bare ridge and plastic-mulched furrow (RFRHS-BR-PMFr); (7) RFRHS with plastic-covered ridge and gravel-sand-mulched furrow (RFRHS-PCR-GMFr); (8) RFRHS with plastic-covered ridge and plastic-mulched furrow plus supplementary irrigation $30 \mathrm{~mm}$ (RFRHS-PCR-PMFr-SI30); (9) RFRHS with 
plastic-covered ridge and plastic-mulched furrow plus supplementary irrigation $90 \mathrm{~mm}$ (RFRHS-PCR-PMFr-SI60); and (10) gravel-sand-mulched field in $8 \mathrm{~cm}$ thickness (GMFd).

- For maize, there were 11 treatments: (1) plastic-mulched field at planting (conventional; PMFd); (2) straw-mulched field during the emergence period (SMFd); (3) gravel-sandmulched field in $8 \mathrm{~cm}$ thickness (GMFd); (4) RFRHS with plastic-covered ridge and bare furrow(RFRHS-PCR-BFr); (5) RFRHS with plastic-covered ridge and straw-mulched furrow during the emergence period (RFRHS-PCR-SMFr); (6) RFRHS with plastic-covered ridge and gravel-sand-mulched furrow (RFRHS-PCR-GMFr); (7) RFRHS with plastic-covered ridge and bare furrow plus supplementary irrigation $30 \mathrm{~mm}$ during the bloom stage (RFRHS-PCR-BFrSI30); (8) RFRHS with plastic-covered ridge and straw mulched furrow during the emergence period plus supplementary irrigation $30 \mathrm{~mm}$ during the bloom (RFRHS-PCR-SMFr-SI30); (9) plastic-mulched field plus supplementary irrigation $30 \mathrm{~mm}$ under the film (PMFd-SI30); (10) plastic-mulched field plus supplementary irrigation $60 \mathrm{~mm}$ under the film (PMFd-SI60); and (11) plastic-mulched field plus supplementary irrigation $90 \mathrm{~mm}$ under the film (PMFd-SI90).

- Gravimetric soil water content was measured at $10 \mathrm{~cm}$ intervals in the 0-40 cm soil depth, and at $20 \mathrm{~cm}$ intervals in the $40-160 \mathrm{~cm}$ soil depth.

- Soil water evaporation was measured using micro-lysimeters.

- The amount of the rainfall was recorded using a standard rain gauge.

- Evapotranspiration (ET) was determined by the following formula: ET $=\Delta \mathrm{W}+\mathrm{P}+\mathrm{I}-\mathrm{D}$. Where $\Delta \mathrm{W}$ is the change in soil water storage $(\mathrm{mm})$ between planting and harvest period or growth stages, $\mathrm{P}$ is the crop growing season precipitation, I is the amount of irrigation ( $\mathrm{mm}$ ) that was measured using a water meter, and D is the amount of water lost due to deep drainage, which was negligible in this study.

- Water use efficiency (WUE) was calculated as $\mathrm{kg}$ of biomass yield produced per $\mathrm{mm}^{-1}$ of water available for crop use.

- At harvesting in 2005 , we dug a soil profile for all mulched treatments to characterize maize rooting patterns (root length and mass).

- In 2006, we compared differences in runoff efficiency between RFRHS with plastic-covered ridge and RFRHS with bare ridge. We collected the runoff water and calculated runoff efficiency for these two treatments after each rainfall.

\section{Summary and Conclusions}

\section{Precipitation (Table 1)}

- There was no effect of RFRHS without plastic-covered ridge on rainwater harvesting for natural precipitation of less than $5 \mathrm{~mm}$ per event. This is because there is little water runoff from frequent low precipitation showers in this area, and most of the harvested rainwater gather on the soil surface, resulting in increased evaporation.

\section{Water Runoff Efficiency (Table 2)}

- For the no plastic covered ridge treatments, only in two out of 10 instances any measurable runoff was detected, when rainfall of $4.6 \mathrm{~mm}$ and $11.6 \mathrm{~mm}$ was recorded. In those two rainfall events, the runoff efficiency was only $5.7 \%$ and $5.5 \%$, which was much lower than the 
corresponding values of $40.5 \%$ and $34.2 \%$ for plastic-covered ridge, clearly showing the positive impact of plastic mulch in increasing the amount of rainwater harvesting.

\section{Water Evaporation (Table 3)}

- Soil water evaporation was lowest for mulching with gravel-sand, and was highest for nonmulching treatment, suggesting significantly more water loss from soil and subsequently less water available for crop use in the growing season in the non-mulched plots.

\section{Root Length Density (Figure 1)}

- The percentage of root length density (RLD) in the $50 \mathrm{~cm}$ depth was highest $(83.6 \%)$ for mulch plus SI $90 \mathrm{~mm}$, followed closely by $82.3 \%$ for RFRHS with straw-mulch plus SI 30 $\mathrm{mm}$, and was lowest (56.6\%) for RFRHS with gravel-sand mulch. This suggests that RFRHS with gravel-sand mulch could make the roots to develop deeper.

\section{Crop Yield and Water Use Efficiency (Tables 4, 5, 6 and 7)}

- In the conventional fields without RFRHS, gravel-sand mulched fields produced higher crop yield than plastic-mulched or straw-mulched fields.

- In the plastic-mulched fields, increasing amount of supplemental irrigation was needed to improve crop yield. In the RFRHS, yield and WUE were higher with plastic-covered ridge than bare ridge, and also higher with gravel-sand-mulched furrow than bare furrow in most cases, or straw-mulched furrow in some cases. This was most likely due to decreased evaporation with plastic or gravel-sand mulch, resulting in increased WUE and crop growth.

- In the RFRHS with plastic-covered ridge and gravel-sand-mulched furrow, application of 30 mm supplemental irrigation produced the highest yield and WUE for maize and sweet sorghum in most cases.

\section{Comparisons of Costs for Different RFRHS Systems (Tables 8, 9 and 10)}

- The estimated costs were 4964 Yuan (\$709) ha ${ }^{-1}$ and 6596 Yuan (942) ha ${ }^{-1}$ for conventional practice (PMFd) with mulch plus irrigation $60 \mathrm{~mm}$ and $90 \mathrm{~mm}$, respectively, and this was considerably higher than all RFRHS treatments.

\section{Acknowledgement}

- This study was funded by the project of Knowledge Innovation from Chinese Academy of Sciences (Grant No. CASN-115-06-08) and the project of Sci-Technology Support from the Ministry of Science and Technology of the People's Republic of China (Grant No. 2006BAD26B0201).

- We thank Erin Cadieu for formatting and printing of this poster. 


\begin{tabular}{|c|c|c|c|c|c|c|}
\hline Year & $\begin{array}{l}\text { Rainfall } \\
\text { times }(\mathrm{T})\end{array}$ & $\begin{array}{c}\text { Rainfall }(<5 \mathrm{~mm}) \\
\text { times }(\mathrm{RT}) \\
\end{array}$ & $\begin{array}{l}\mathrm{RT} / \mathrm{T} \\
(\%) \\
\end{array}$ & $\begin{array}{c}\text { Total } \\
\text { amount }(\mathrm{A})(\mathrm{mm})\end{array}$ & $\begin{array}{c}\text { Rainfall }(<5 \mathrm{~mm}) \\
\text { amount }(\mathrm{RA}) \\
(\mathrm{mm})\end{array}$ & $\begin{array}{l}\text { RA/A } \\
(\%)\end{array}$ \\
\hline 2001 & 38 & 23 & 60.5 & 239 & 53 & 22.0 \\
\hline 2002 & 28 & 12 & 42.9 & 241 & 30 & 12.6 \\
\hline 2003 & 38 & 25 & 65.8 & 278 & 69 & 24.8 \\
\hline 2004 & 32 & 19 & 59.4 & 187 & 36 & 19.4 \\
\hline 2005 & 44 & 31 & 70.5 & 170 & 58 & 34.2 \\
\hline 2006 & 46 & 34 & 73.9 & 229 & 66 & 28.9 \\
\hline
\end{tabular}

Table 2. Comparisons of runoff efficiency (RE) of rainwater between ridge and furrow rainfall harvesting systems (RFRHS) with plastic-covered ridge and bare ridge in a field without crop at Gaolan, Gansu, China in 2006

\begin{tabular}{|c|c|c|c|c|}
\hline \multirow[b]{2}{*}{ Date } & \multirow{2}{*}{$\begin{array}{l}\text { Rainfall } \\
\text { (mm) }\end{array}$} & \multicolumn{3}{|c|}{$\mathrm{RE}(\%)$} \\
\hline & & Plastic-covered ridge (PCR) & Bare ridge (BR) & $\begin{array}{c}\text { Difference between } \\
\text { PCR and BR }\end{array}$ \\
\hline July 27 & 11.6 & 34.2 & 5.5 & $+28.7^{* *}$ \\
\hline July 30 & 3.6 & 10.6 & 0.0 & $+10.6^{* *}$ \\
\hline August 2 & 0.4 & 29.1 & 0.0 & $+29.1 * *$ \\
\hline August 6 & 1.7 & 28.7 & 0.0 & $+28.7 * *$ \\
\hline August 11 & 3.2 & 36.9 & 0.0 & $+36.9 * *$ \\
\hline August 16 & 4.6 & 40.5 & 5.7 & $+34.8 * *$ \\
\hline August 22 & 1.1 & 36.4 & 0.0 & $+36.4 * *$ \\
\hline August 29 & 0.9 & 25.0 & 0.0 & $+25.0 * *$ \\
\hline August 31 & 4 & 39.1 & 0.0 & $+39.1 * *$ \\
\hline September 5 & 2.4 & 28.7 & 0.0 & $+28.7 * *$ \\
\hline Mean & & 30.9 & 1.1 & $+29.8 * *$ \\
\hline
\end{tabular}

** refers to significant treatment effect for $\mathrm{RE}$ in paired t-test at $\mathrm{P} \leq 0.01$.

Table 3. Comparisons of evaporation of water from soil among different mulching patterns in ridge and furrow rainfall harvesting system (RFRHS) in maize from August to September at Gaolan, Gansu, China in 2006

\begin{tabular}{lccc} 
& Foot of the ridge & $1 / 4$ of the furrow & $1 / 2$ of the furrow \\
\hline RFRHS-PCR-SMFr & 0.53 & 0.56 & 0.54 \\
RFRHS-PCR-GMFr & 0.47 & 0.35 & 0.32 \\
RFRHS-PCR-BFr & 0.76 & 0.67 & 0.62
\end{tabular}


Table 4. Total water use, water use efficiency (WUE) and biomass yield of sweet sorghum, with different water use and water harvest treatments at Gaolan, Gansu, China in 2005.

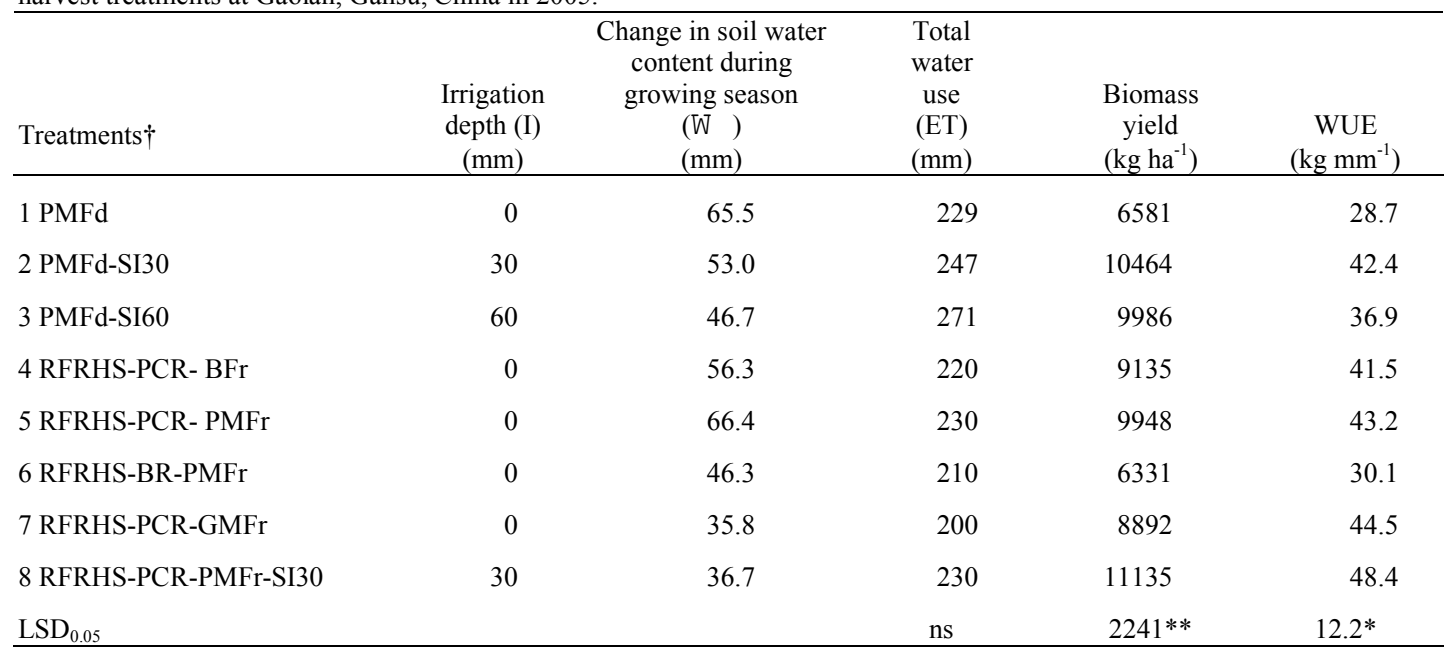

$*, * *$ and ns refer to significant treatment effect in ANOVA at $\mathrm{P} \leq 0.01, \mathrm{P} \leq 0.05$ and not significant, respectively.

Precipitation in the growing season was $164 \mathrm{~mm}$.

Table 5. Total water use, water use efficiency (WUE) and biomass yield of sweet sorghum, with different water use and water harvest treatments at Gaolan, Gansu, China in 2006.

\begin{tabular}{|c|c|c|c|c|c|}
\hline Treatments & $\begin{array}{c}\text { Irrigation } \\
\text { depth (I) } \\
(\mathrm{mm})\end{array}$ & $\begin{array}{l}\text { Change in soil } \\
\text { water content } \\
\text { during growing } \\
\text { season }(\Delta \mathrm{W}) \\
(\mathrm{mm})\end{array}$ & $\begin{array}{l}\text { Total } \\
\text { Water } \\
\text { Use } \\
(\mathrm{ET}) \\
(\mathrm{mm}) \\
\end{array}$ & $\begin{array}{c}\text { Biomass } \\
\text { yield } \\
\left(\mathrm{kg} \mathrm{ha}^{-1}\right)\end{array}$ & $\begin{array}{c}\text { WUE } \\
\left(\mathrm{kg} \mathrm{mm}^{-1}\right)\end{array}$ \\
\hline $1 \mathrm{PMFd}$ & 0 & 84.6 & 285 & 7808 & 27.4 \\
\hline 2 PMFd-SI30 & 30 & 88.1 & 318 & 9076 & 28.5 \\
\hline 3 PMFd-SI60 & 60 & 97.8 & 358 & 10022 & 28.0 \\
\hline 4 RFRHS-PCR-BFr & 0 & 100.6 & 301 & 10262 & 34.1 \\
\hline 5 RFRHS-PCR-PMFr & 0 & 117.2 & 317 & 7935 & 25.0 \\
\hline 6 RFRHS-BR-PMFr & 0 & 94.4 & 295 & 7213 & 24.5 \\
\hline 7 RFRHS-PCR-GMFr & 0 & 107.3 & 308 & 9364 & 30.5 \\
\hline 8 RFRHS-PCR-PMFr-SI30 & 30 & 95.8 & 326 & 11796 & 36.2 \\
\hline 9 RFRHS-PCR-PMFr-SI60 & 60 & 85.0 & 345 & 11351 & 32.9 \\
\hline 10 GMFd & 0 & 116.1 & 316 & 10511 & 33.2 \\
\hline $\mathrm{LSD}_{0.05}$ & & & $32 * *$ & $2568 * *$ & ns \\
\hline
\end{tabular}

** and ns refer to significant treatment effect in ANOVA at $\mathrm{P} \leq 0.01$ and not significant, respectively.

Precipitation in the growing season was $200 \mathrm{~mm}$. 
Table 6. Total water use, water use efficiency (WUE) and biomass yield of sweet maize, with different water use and water harvest treatments at Gaolan, Gansu, China in 2005.

\begin{tabular}{|c|c|c|c|c|c|}
\hline Treatments & $\begin{array}{l}\text { Irrigation } \\
\text { depth (I) } \\
(\mathrm{mm})\end{array}$ & $\begin{array}{l}\text { Change in soil } \\
\text { water content } \\
\text { during growing } \\
\text { season }(\Delta \mathrm{W}) \\
(\mathrm{mm})\end{array}$ & $\begin{array}{l}\text { Total } \\
\text { Water } \\
\text { Use } \\
(\mathrm{ET}) \\
(\mathrm{mm}) \\
\end{array}$ & $\begin{array}{c}\text { Biomass } \\
\text { yield } \\
\left(\mathrm{kg} \mathrm{ha}^{-1}\right)\end{array}$ & $\begin{array}{c}\text { WUE } \\
\left(\mathrm{kg} \mathrm{mm}^{-1}\right)\end{array}$ \\
\hline 1 PMFd & 0 & 90.6 & 241 & 1474 & 6.1 \\
\hline $2 \mathrm{SMFd}$ & 0 & 102.0 & 252 & 1029 & 4.0 \\
\hline $3 \mathrm{GMFd}$ & 0 & 104.1 & 254 & 2322 & 9.2 \\
\hline 4 RFRHS-PCR-BFr & 0 & 107.9 & 258 & 2382 & 9.1 \\
\hline 5 RFRHS-PCR-SMFr & 0 & 103.6 & 254 & 3047 & 11.8 \\
\hline 6 RFRHS-PCR-GMFr & 0 & 48.6 & 199 & 2799 & 14.1 \\
\hline 7 RFRHS-PCR-BFr-SI30 & 30 & 75.5 & 256 & 3325 & 13.2 \\
\hline 8 RFRHS-PCR-SMFr-SI30 & 30 & 89.1 & 269 & 2445 & 9.1 \\
\hline 9 PMFd-SI30 & 30 & 118.1 & 298 & 2456 & 8.2 \\
\hline 10 PMFd-SI60 & 60 & 79.6 & 290 & 4172 & 14.4 \\
\hline 11 PMFd-SI90 & 90 & 72.6 & 313 & 6050 & 19.4 \\
\hline $\mathrm{LSD}_{0.05}$ & & & $58^{*}$ & $1191 * *$ & $5.3 * *$ \\
\hline
\end{tabular}

* and ${ }^{* *}$ refer to significant treatment effect in ANOVA at $\mathrm{P} \leq 0.05$ and $\mathrm{P} \leq 0.01$, respectively.

Precipitation in the growing season was $150 \mathrm{~mm}$.

Table 7. Total water use, water use efficiency (WUE) and biomass yield of sweet maize, with different water use and water harvest treatments at Gaolan, Gansu, China in 2006

\begin{tabular}{|c|c|c|c|c|c|}
\hline Treatments & $\begin{array}{c}\text { Irrigation } \\
\text { depth (I) } \\
(\mathrm{mm})\end{array}$ & $\begin{array}{l}\text { Change in soil } \\
\text { water content } \\
\text { during growing } \\
\text { season }(\Delta \mathrm{W}) \\
(\mathrm{mm}) \\
\end{array}$ & $\begin{array}{l}\text { Total } \\
\text { Water } \\
\text { Use } \\
(\mathrm{ET}) \\
(\mathrm{mm}) \\
\end{array}$ & $\begin{array}{c}\text { Biomass } \\
\text { yield } \\
\left(\mathrm{kg} \mathrm{ha}^{-1}\right)\end{array}$ & $\begin{array}{r}\text { WUE } \\
\left(\mathrm{kg} \mathrm{m}^{-1}\right) \\
\end{array}$ \\
\hline 1 PMFd & 0 & 40.7 & 255 & 551 & 2.1 \\
\hline $2 \mathrm{SMFd}$ & 0 & 45.6 & 260 & 199 & 0.8 \\
\hline $3 \mathrm{GMFd}$ & 0 & 66.3 & 281 & 1382 & 5.0 \\
\hline 4 RFRHS-PCR-BFr & 0 & 43.1 & 258 & 1124 & 4.3 \\
\hline 5 RFRHS-PCR-SMFr & 0 & 52.0 & 267 & 694 & 2.7 \\
\hline 6 RFRHS-PCR-GMFr & 0 & 68.4 & 283 & 3129 & 10.9 \\
\hline 7 RFRHS-PCR-BFr-SI30 & 30 & 40.6 & 285 & 2332 & 8.1 \\
\hline 8 RFRHS-PCR-SMFr-SI30 & 30 & 71.8 & 317 & 2961 & 9.1 \\
\hline 9 PMFd-SI30 & 30 & 39.1 & 284 & 1397 & 4.9 \\
\hline 10 PMFd-SI60 & 60 & 47.5 & 322 & 2270 & 7.0 \\
\hline 11 PMFd-SI90 & 90 & 61.4 & 366 & 2383 & 6.5 \\
\hline $\mathrm{LSD}_{0.05}$ & & & $39 * *$ & $961 * *$ & $2.9 * *$ \\
\hline
\end{tabular}

** refer to significant treatment effect in ANOVA at $\mathrm{P} \leq 0.01$.

Precipitation in the growing season was $215 \mathrm{~mm}$. 


\begin{tabular}{|c|c|c|c|c|c|}
\hline \multirow[b]{2}{*}{ Catchments } & \multirow{2}{*}{$\begin{array}{l}\text { Annual runoff } \\
\text { efficiency }(\%)\end{array}$} & \multicolumn{2}{|c|}{$\begin{array}{l}\text { Cost of preparing for } \\
\text { harvesting rainwater }\end{array}$} & \multicolumn{2}{|c|}{$\begin{array}{c}\text { Cost for rainwater } \\
\text { harvesting based on } 300 \\
\text { mm annual rainfall }\end{array}$} \\
\hline & & Yuan $\mathrm{m}^{-2}$ & $\$ \mathrm{ha}^{-1}$ & Yuan $\mathrm{m}^{-3}$ & $\$ \mathrm{~m}^{-3}$ \\
\hline Cleared loess slope & 12.5 & 0.08 & 114 & 2.13 & 0.30 \\
\hline Old plastic mulch surface & 66.6 & 0.05 & 71 & 0.25 & 0.04 \\
\hline Road & 75.0 & 0.05 & 71 & 0.22 & 0.03 \\
\hline Roof of house & 58.3 & 0.05 & 71 & 0.29 & 0.04 \\
\hline
\end{tabular}

Table 9. Storage costs of rainwater harvesting for different storage tank at Gaolan, Gansu, China

\begin{tabular}{lcccc}
\hline Tank types & Storage capacity $\left(\mathrm{m}^{3}\right)$ & $\begin{array}{c}\text { Service life } \\
(\mathrm{yr})\end{array}$ & $\begin{array}{c}\text { Cost of building } \\
\text { tanks }(\text { Yuan } / \$)\end{array}$ & $\begin{array}{c}\text { Storage cost } \dagger \\
\left.\mathrm{m}^{-3} / \$ \mathrm{~m}^{-3}\right)\end{array}$ \\
\hline Sand-soil-plastic storage tank & 25 & 5 & $414(59)$ & $3.31(0.47)$ \\
Concrete tank with thin wall & 25 & 8 & $820(117)$ & $4.10(0.59)$ \\
Clay tank & 50 & 8 & $1640(234)$ & $4.10(0.59)$ \\
Big concrete tank & 100 & 15 & $9600(1371)$ & $6.40(0.91)$ \\
Concrete tank & 25 & 15 & $2500(357)$ & $6.67(0.95)$ \\
\hline
\end{tabular}

$\dagger$ Storage cost $=$ Total cost $/$ storage capacity $\times$ service life.

Table 10. Comparisons of costs between ridge and furrow rainfall harvesting system (RFRHS) and mulch surface at Gaolan, Gansu, China

\begin{tabular}{|c|c|c|c|}
\hline Catchments & $\begin{array}{c}\text { Annual } \\
\text { labor cost } \dagger \\
\left(\text { Yuan } / \$ \mathrm{ha}^{-1}\right)\end{array}$ & $\begin{array}{l}\text { Annual cost for } \\
\text { mulch materials } \\
\left(\text { Yuan } / \$ \mathrm{ha}^{-1}\right)\end{array}$ & $\begin{array}{c}\text { Total annual } \\
\text { cost } \\
\left(\text { Yuan } / \$ \mathrm{ha}^{-1}\right) \\
\end{array}$ \\
\hline Conventional field (without RFRHS) & $1200(171)$ & $0(0)$ & $1200(171)$ \\
\hline RFRHS with plastic mulch ridge & $1800(257)$ & $900(129)$ & $2700(386)$ \\
\hline RFRHS with plastic-covered ridge and furrow & $1800(257)$ & $1440(206)$ & $3240(463)$ \\
\hline RFRHS with plastic-covered ridge and straw- mulched furrow & $1800(257)$ & $1350(193)$ & $3150(450)$ \\
\hline RFRHS with plastic-covered ridge and gravel-sand-mulched furrow & $1800(257)$ & $1575(225)$ & $3375(482)$ \\
\hline
\end{tabular}

$\dagger$ Labor cost is 20 Yuan per one, the cost for gravel-sand is 90 yuan $\mathrm{m}^{-3}$, plastic is 12 yuan $\mathrm{kg}^{-1}$ and the cost for straw is $0.15 \mathrm{Yuan}_{\mathrm{kg}}^{-1}$. 

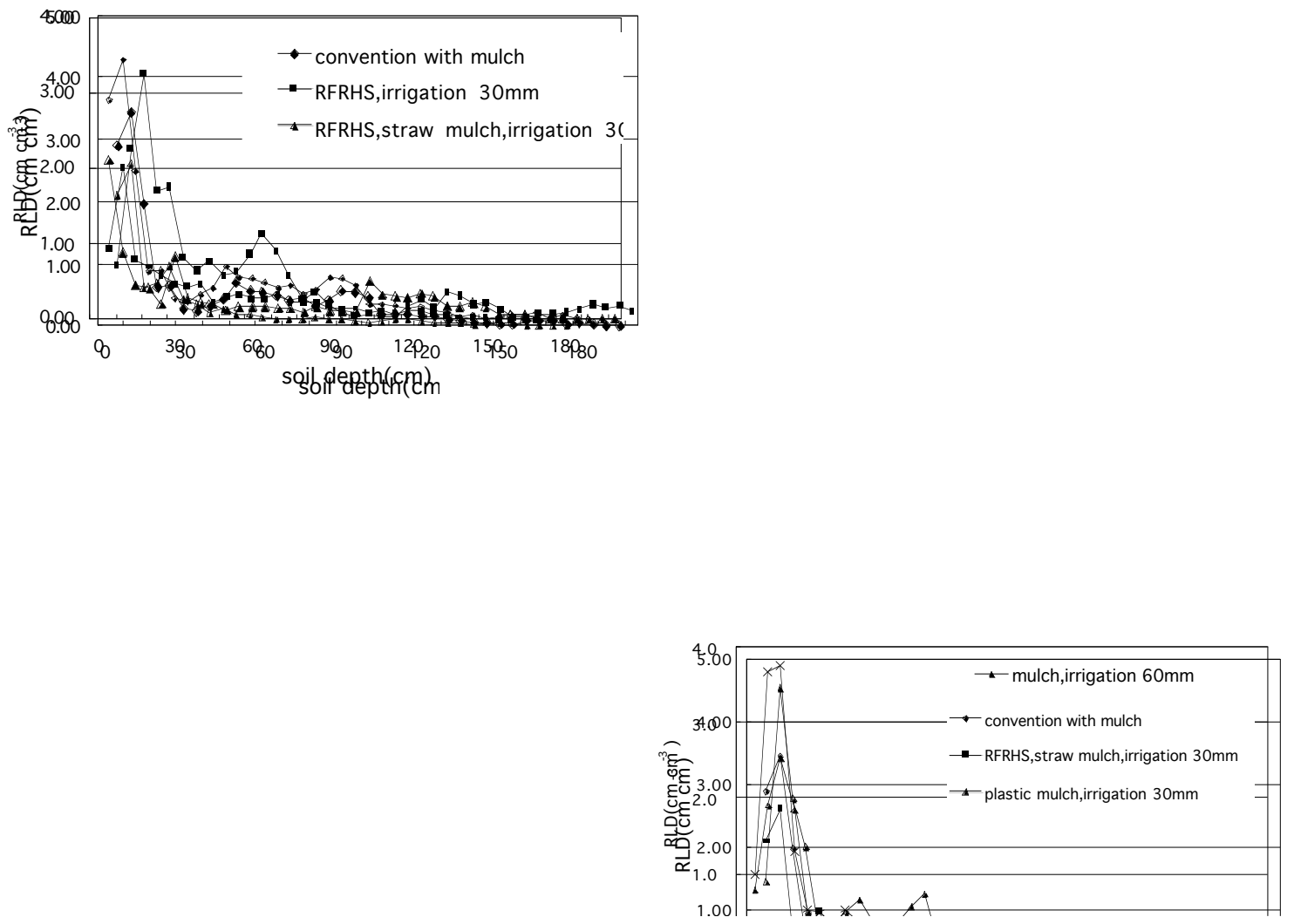

Figure 1. Root length density (RLD) in different treatments for maize in 2005 at Gaolan, Gansu, China 